\title{
Book Review: The Drowned and the Saved
}

\author{
Michael Polgar* \\ Department of Sociology, Penn State University, Hazleton, PA, United States
}

Keywords: holocaust, survival, education, memory, Auschwitz

\begin{abstract}
A Book Review on
The Drowned and the Saved

Primo Levi (New York, NY: Simon \& Schuster; Reissue edition), 2017, 208 pages,

ISBN-13: 978-1501167638.
\end{abstract}

We join international efforts to share inclusive and respectful pedagogies, helping us to learn both about and from the Holocaust (Cowan and Henry, 2017). Holocaust survivors texts and testimonies provide us with historical primary sources and with inspiration for resilience. Some survivors have followed this credo: we bear witness and the weight of memory, whether we like it or not (Bigsby, 2006).

Primo Levi's final book, “The Drowned and the Saved," elaborates memory of Auschwitz (Levi, 1989); a recent biography elaborates Levi's life (Thomson, 2002). "Drowned” is a book-end to Levi's first testimonial, "Survival in Auschwitz", first published in 1947 (Levi, 1986). "Survival” offers primarily testimony; "Drowned" includes more reflection and judgement (Druker, 1994). Levi's memory and reflection describes and indicts criminal injustices with deep memories of Auschwitz; Anguished memory remains, "Nothing makes you free" (Bukiet, 2002). We are indebted to the pained testimonies of survivors, including Levi.

The author worked for 11 months in Auschwitz III, a Nazi labor camp adjacent to the infamous

Edited by:

Sandro Serpa,

University of the Azores, Portugal

Reviewed by:

Carlos Miguel Ferreira, Instituto Politécnico de Castelo Branco, Portugal

*Correspondence: Michael Polgar mfp11@psu.edu

Specialty section:

This article was submitted to

Sociological Theory,

a section of the journal

Frontiers in Sociology

Received: 31 May 2018

Accepted: 04 July 2018

Published: 25 July 2018

Citation:

Polgar M (2018) Book Review: The

Drowned and the Saved.

Front. Sociol. 3:21.

doi: 10.3389/fsoc.2018.00021 death camp. Levi was an Italian chemist who synthesized rubber (Bigsby, 2006). Levi's survival strategies (he was one of 'the Saved") are interspersed with the horrors of the less fortunate who "Drowned." After his liberation in 1945, he spent almost a year getting home and then wrote his first book; it was rejected by six publishers before being published in 1947. "Survival" was only popular after being translated into English in 1958 and republished (Bigsby, 2006).

Levi became a writer-witness against perpetrators. In "Drowned," he reminds us that the Nazi officials tried to cover up their crimes when their loss in war seemed certain (Levi, 1989). As educators, we remember to share information that many fought and died to preserve, a chain of Holocaust memory, which Nazi perpetrators disguised and intended to remain hidden.

Levi preserves memories to witness the offenses committed by the Nazi totalitarian state through propaganda, terror, and "barriers... against pluralism of information" (Levi, 1989). The "processing" and treatment of people-turned-prisoners was cruel, unusual, intentional, and degrading. Violent rituals committed by armed and enraged functionaries were followed by stripping and beatings, shaving and redressing in rags. Hunger and thirst were familiar enemies. Educators and learners may be put off by horrific details, but cruel and harsh conditions may not be ignored altogether.

Should educators shield learners from this real and revolting violence? Levi himself raises the less violent alternative of Anne Frank, whose diary provides moments of hope for humanity, an early post-war example of empowered resilience, and the basis for transformative popular theatrical productions and Holocaust consciousness (Brenner, 1997; Prose, 2009). Levi's "The Truce" was also theatrically produced, by CBC as a Canadian Radio play (Bigsby, 2006). We remember through many forms of media and varieties of human experiences. 
In "Drowned," Levi elaborates "gray zones," ambiguities of interpretation that remain after we simplify history, uncertainties about the meanings of traumatized memories (Levi, 1989). Levi reflects on feelings that were misunderstood as shame or communication-impaired silence after liberation. He reminds us that some survivors had experiences of or survived by assuming privileges. While Nazis were responsible for inhumane conditions, some prisoners chose or needed to become selfinterested to a fault; the tension between survivor-cooperation and self-interest is a point where Levi and Wiesel publically disagreed (Bigsby, 2006).

How can educators describe or represent mistreatment during the Holocaust? Levi writes that "twelve Hitlerian years... were characterized by widespread useless violence" for the purposes of inflicting pain (Levi, 1989). Persecution was intended and directed. Perpetrators were "rationally" mean, putting unjust law and violence to use for social control, applying military aggression and terror. Life in camps started with a departure: a sealed cattle car becomes a prison-on-wheels, conveying "human material" to distant locations, followed by plunder and cruelty, leading toward sites of mass murder.

As a scientist, Levi had the "benefit" of wartime work, forced labor rather than "extermination," and a number $(174,517$, a permanent tattoo). While dehumanizing, numerical classification protected many workers against death-by-incineration. Still, his culture and education had disadvantages; "intellectuals" were subject to harm and special antisemitic degradations. In Auschwitz and beyond, faith and ritual were difficult and materially challenged during the Holocaust; books and reading were often prohibited (Levi, 1989).

In "Drowned," Levi distinguishes people who speak up from those who remain silent. Survivors who speak up in the (including Levi) are asked why they did not rebel, avoid capture, or escape (Levi, 1989). Levi writes that this assumes escape is a moral obligation and that a prisoner's condition is somehow illegitimate in the context of our presumably free world. But "Holocaust camp" prisoners were routinely harmed, overworked, starved, cut off, and degraded. Prisoners were often foreigners with limited communication capacities, subject to horrid conditions without clean or sufficient clothing, and under

\section{REFERENCES}

Bigsby, C. W. E. (2006). Remembering and Imagining the Holocaust: The Chain of Memory. Cambridge; New York, NY: Cambridge University Press.

Brenner, R. F. (1997). Writing as Resistance: Four Women Confronting the Holocaust: Edith Stein, Simone Weil, Anne Frank, Etty Hillesum. University Park, PA: Pennsylvania State University Press.

Bukiet, M. J. (2002). Nothing Makes You Free: Writings by Descendants of Jewish Holocaust Survivors, 1st Edn. New York, NY: W.W. Norton.

Cowan, P., and Henry, M. (2017). Understanding and Teaching Holocaust Education. Los Angeles, CA; London: Sage Publications.

Druker, J. (1994). Primo Levi's survival in auschwitz and the drowned and the saved: from testimony to historical judgment. Shofar 12, 47-58. doi: 10.1353/sho.1994.0101

Lengyel, O. (1995). Five chimneys. Chicago, IL: Academy Chicago Publishers.

Levi, P. (1986). Survival in Auschwitz: The Nazi Assault on Humanity. New York, NY: Collier Books. careful surveillance, forced to speak his number at roll call, often at penalty of death. In Nazi-controlled conditions, any allies also risked severe punishment. Multiple authors testify that attempts to escape were desperate and doomed (Lengyel, 1995).

Levi's work reminds us that retrospective interpretations can be based on stereotypes (Levi, 1989). Severe oppression was designed to weaken, demoralize, and prevent the potential for conflict; even pregnant women were brutally harmed in Auschwitz (Lengyel, 1995). To resist or rebel was often to choose death, creating one of many impossible, "choiceless choices." Subjecting survivors to interrogation or alternative scenarios in hindsight is to blame a victim for the crimes of the Nazis.

This raises an important lesson: innocent victims of any crime are not obligated to explain their own motives or behaviors, nor the motives driving perpetrators of crime. Crime is immoral. This lesson should become clearer to modern audiences; there need be no shame in being subject to racism, sexism, or any form of oppression. Survivors of crime, like Levi and others, may testify in a "court of public education," but testimonial memories need not be subject to hostile cross-examinations that subject victims to false accusations.

\section{AUTHOR CONTRIBUTIONS}

The author confirms being the sole contributor of this work and approved it for publication.

\section{FUNDING}

The author thanks Penn State University (Hazleton Campus) for research development support to explore topics in Holocaust education.

\section{ACKNOWLEDGMENTS}

The author thanks The Olga Lengyel Institute (TOLI.us) and the United States Holocaust Memorial and Museum (USHMM.org) and their partner-organizations for generous support through educator training in Holocaust studies.

Levi, P. (1989). The Drowned and the Saved, 1st Vintage International Edn. New York, NY: Vintage International.

Prose, F. (2009). Anne Frank: The Book, the Life, the Afterlife, 1st Edn. New York, NY: Harper.

Thomson, I. (2002). Primo Levi. London: Hutchinson.

Conflict of Interest Statement: The author declares that the research was conducted in the absence of any commercial or financial relationships that could be construed as a potential conflict of interest.

Copyright (c) 2018 Polgar. This is an open-access article distributed under the terms of the Creative Commons Attribution License (CC BY). The use, distribution or reproduction in other forums is permitted, provided the original author(s) and the copyright owner(s) are credited and that the original publication in this journal is cited, in accordance with accepted academic practice. No use, distribution or reproduction is permitted which does not comply with these terms. 